\title{
ANALISIS KARAKTERISTIK LAPISAN SEDIMEN BERDASARKAN DATA MIKROTREMOR DI AREA RUMAH SAKIT PENDIDIKAN UNILA
}

\section{ANALYSIS OF SEDIMENT CHARACTERISTIC BASED ON MICROTREMOR DATA IN AREA OF RUMAH SAKIT PENDIDIKAN UNILA}

\author{
Hesti $^{1 *}$, Suharno ${ }^{2}$, Rahmi Mulyasari ${ }^{3}$, Akroma Hidayatika ${ }^{4}$ \\ 1,2,3,4 Jurusan Teknik Geofisika, Fakultas Teknik, Universitas Lampung
}

Received: 2020, December $7^{\text {th }}$ A ccepted: 2021, July $8^{\text {th }}$

\author{
Keyword: \\ Amplification; \\ Dominant frequency; \\ HVSR; \\ Sediment; \\ Unila Educational Hospital.
}

\section{Corespondent Email:}

hesti.9201@eng.unila.ac.id

\author{
H ow to cite this article: \\ Hesti, Suharno, M ulyasari, R., \\ \& Hidayatika, A. (2021). \\ A nalisis K arakteristik Lapisan \\ Sedimen Berdasarkan Data \\ M ikrotremor dan A nalisis \\ Geologi di Area Pembangunan \\ Rumah Sakit U niversitas
}

\begin{abstract}
Abstrak. Provinsi Lampung memiliki kondisi geografis kompleks, dilewati jalur Bukit Barisan dan terletak diantara dua lempeng yaitu Indo-Australia dan Eurasia. Provinsi Lampung juga merupakan wilayah yang dekat dengan Samudera Hindia dan terletak pada zona Sesar Semangko (Sumatra Transform Fault Zone) yang terbentang dari Aceh sampai Teluk Semangka Lampung. Dengan demikian penataan wilayah dan pembangunan infrastruktur yang berbasis mitigasi gempabumi merupakan hal yang sangat penting dilakukan. Tujuan penelitian ini adalah mengetahui karakteristik lapisan batuan sedimen pada area pembangunan Rumah Sakit Pendidikan Universitas Lampung (RSP Unila) sebagai bagian dari tahapan mitigasi bencana gempabumi. Penelitian ini dilakukan dengan menggunakan metode mikrotremor dan analisis geologi permukaan. Data pengukuran metode mikrotremor dianalisis dengan menggunakan metode analisis Horizontal Vertical Spectrum Ratio (HVSR) untuk mendapakan nilai amplifikasi $\left(A_{0}\right)$ dan frekuensi dominan $\left(\mathrm{f}_{0}\right)$. Hasil dari analisis HVSR diperoleh nilai frekuensi dominan $\left(f_{0}\right)$ berkisar $0.65-1.2 \mathrm{~Hz}$, amplifikasi $\left(A_{0}\right)$ berkisar 3.33-5.62, dan nilai periode dominan $\left(T_{0}\right)$ 0.6-1.5 sekon. Nilai $A_{0}, f_{0}, T_{0}$ diinterpreasikan dengan mengacu data literatur dan geologi permukaan yang relevan. $\mathrm{H}$ asilnya menunjukkan bahwa daerah penelitian memiliki jenis lapisan sedimen yang rentan terhadap peristiwa gempabumi.
\end{abstract}

\footnotetext{
A bstract. Lampung Province is in a complex geographical condition, its area is traversed by Bukit Barisan and located between two plates, namely the IndoAustralian and the Eurasian. Lampung Province is near with the Indian Ocean and it's located in the Semangko Fault Zone (Sumatra Transform Fault Zone)
} 
Lampung. Jurnal Geofisika Eksplorasi, 7(2), 150-159.

(C) 2021 JGE (Jurnal Geofisika Eksplorasi). This article is an openaccess article distributed under the terms and conditions of the Creative Commons Attribution (CC BY NC) which stretches from A ceh to Teluk Semangka Lampung. Thus, spatial planning and infrastructure development based on mitigation earthquakes are very important things to do in this area. The purpose of this study was to determine the disasters of rock layers in the construction area of the Rumah Sakit Pendidikan (RSP) Unila as part of the earthquake disaster mitigation phase. This research was conducted using the microtremor method and surface geological analysis. The method of measuring microtremor data was analyzed using the Horizontal Vertical Spectrum Ratio (HVSR) method to get the amplification value $\left(A_{0}\right)$ and the dominant frequency $\left(f_{0}\right)$. The results of the HVSR analysis showed the dominant frequency $\left(f_{0}\right)$ ranged from 0.65 to $1.2 \mathrm{~Hz}$, the amplification $\left(A_{0}\right)$ ranged from 3.33 to 5.62 , and the dominant period value (To) from 0.6 to 1.5 seconds. Then the interpretation is carried out by analyzing the $A_{0}, f_{0}, T_{0}$ value with the relevant literature and surface geology data. The results show that the study area is vurnerable to the earthquakes.

\section{PENDAHULUAN}

Bandar Lampung merupakan ibu kota Provinsi Lampung. Provinsi Lampung memiliki kondisi geografis kompleks, dilewati jalur Bukit Barisan dan terletak diantara dua lempeng yaitu Indo-Australia dan Eurasia. Provinsi Lampung juga merupakan wilayah yang dekat dengan Samudera Hindia dan terletak pada zona Sesar Semangko (Sumatra Transform Fault Zone) yang terbentang dari Aceh sampai Teluk Semangka Lampung dengan kisaran panjang mencapai $900 \mathrm{~km}$ (BMKG, 2021). Lempeng tektonik selalu mengalami pergerakan secara dinamis dan pergerakan ini dapat dirasakan hingga permukaan bumi yang sering sebut sebagai peristiwa gempabumi tektonik. Pergerakan lempeng samudra di bawah laut dapat memicu terjadinya gempa bawah laut dan menyebabkan gelombang pasang tsunami. Diketahui lempeng tektonik Indo-Australia mengalami pergerakan dengan kecepatan 6 $\mathrm{cm} /$ tahun sampai dengan $14 \mathrm{~cm} /$ tahun. $\mathrm{Hal}$ ini tentunya membuat Provinsi Lampung rentan terhadap peristiwa gempabumi. Penataan wilayah dan pembangunan infrastruktur yang berbasis mitigasi gempabumi adalah hal yang sangat penting dan harus dilakukan pada wilayah yang rentan terjadinya gempabumi.
Universitas Lampung merupakan universitas negeri yang berada di kota Bandar Lampung, Provinsi Lampung. Universitas Lampung berusaha memberikan manfaat yang lebih besar kepada masyarakat dengan membangun sarana pendidikan dan kesehatan berupa rumah sakit. Pembangunan rumah sakit tentunya harus mengacu pada prinsip pembangunan berkelanjutan (sustainable development) sehingga mampu menjadi fasilitas umum yang dapat dimanfaatkan secara terus menerus. Suatu daya dukung lingkungan atau "sustain" dalam pembangunan berkelanjutan adalah suatu upaya dalam menjaga apa yang menjadi milik kita agar tetap ada (M ulyaningsih, 2010).

Salah satu upaya untuk menjaga Rumah Sakit Pendidikan Unila agar sustain adalah dengan membangunan fasilitas umum ini dengan berbasis pada mitigasi gempabumi, mengingat keberadaan Rumah Sakit ini pada lokasi yang rawan gempabumi.

Migrasi awal yang perlu dilakukan adalah mengetahui karakteristik lapisan batuan sedimen di wilayah ini. Lapisan batuan sedimen dengan frekuensi rendah dan amplifikasi tinggi dapat memberikan respon gelombang yang semakin besar dan memberikan guncangan yang semakin besar pada infrastruktur di permukaan bumi. Informasi 
mengenai frekuensi lapisan batuan sangat penting untuk menghindari terjadinya resonansi terhadap bangunan yang memiliki tingkat frekuensi yang sama apabila gempabumi terjadi (M ucciarelli dkk., 2007).

M etode geofisika adalah metode yang dapat digunakan untuk mendapatkan informasi perihal kondisi bawah permukaan. Lapisan sedimen di bawah permukaan dapat di deteksi dengan salah satu metode geofisika yaitu metode mikrotremor. Metode mikrotremor merupakan metode yang efektif untuk mengetahui karakteristik lapisan bawah permukaan. M etode mikrotremor merupakan metode yang efektif, murah dan dapat diterapkan di lingkungan perkotaan (M ucciarelli dkk., 2007).

M etode mikroremor tel ah digunakan dalam berbagai macam kasus untuk menyelidiki bawah permukaan terutama untuk studi gempabumi. Satria dkk. (2019) melakukan penelitian menggunakan metode mikrotremor dengan analisis HVSR untuk mengetahui karakteristik indeks kerentanan seismik di Kota Jambi. Daryono (2011) melakukan penelitian menggunakan metode mikrotremor untuk menganalisis seismisitas di area Graben Bantul. Jamroni dkk. (2017) melakukan penelitian dengan metode mikrotremor dan analisis HVSR di Makassar untuk mengetahui karakteristik lapisan sedimen dan hubungannya dengan kerusakan bangunan akibat Gempa Makassar tahun 2015. Marsyelina dkk. (2014) melakukan penelitian pada jalur sesar Opak, Kabupaten Bantul, Yogyakarta. Hesti dkk. (2018) melakukan penelitian untuk analisis gempa di daerah Prambanan Yogyakarta-Jawa tengah.

Pada penelitian ini dilakukan analisis lapisan batuan di bawah permukaan pada area pembangunan Rumah Sakit Pendidikan Universitas Lampung (RSP Unila) dengan metode mikrotremor dan analisis geologi. Tujuan dari penelitian ini adalah mengetahui karakteristik lapisan batuan sedimen pada area pembangunan Rumah Sakit Pendidikan Universitas Lampung sebagai bagian dari tahapan mitigasi bencana gempabumi. Penelitian ini dilakukan sebagai upaya untuk menunjang pembangunan fasilitas umum yang berkelanjutan.

\section{TINJAUAN PUSTAKA}

\subsection{Geologi Daerah Penelitian}

Daerah Penelitian secara geografis berada di Kota Bandar Lampung, Provinsi Lampung. Kota Bandar Lampung adalah wilayah yang memiliki dataran bergelombang dan ketinggian topografi 200 - 300 meter diatas permukaan laut. Lahan pada wilayah ini banyak dimanfaatkan sebagai area pertanian, perkebunan, dan pemukiman.

Menurut (Mangga dkk., 1993), Secara regional daerah penelitian terdiri dari 3 formasi batuan yaitu:

- Endapan Alluvium dengan komposisi pasir, lempung dan kerikil

- Endapan Gunung api Muda dengan komposisi lava, andesit, breksi dan tuf

- Formasi Lampung dengan komposisi Tuf berbatu apung, tuf riolitik, tuf padu tufit, batu lempung tufan dan batu pasir tufan.

Geologi regional daerah penelitian dapat dilihat pada (Gambar 1).

\subsection{Gempabumi dan Respon Lapisan Batuan Sedimen (Tanah)}

Gempabumi merupakan getaran yang terjadi di permukaan bumi, yang diakibatkan oleh pergerakan kerakbumi (Mulyaningsih, 2010). Gerakan tersebut dapat disebabkan karena beberapa faktor seperti tumbukan antar lempeng bumi, patahan aktif (sesar), aktivitas gunungapi dan runtuhan batuan.

Gelombang gempabumi akan memberikan efek ke permukaan bumi tergantung pada besarnya magnitudo gempa dan kondisi geologi permukaan suatu daerah. Kondisi geologi permukaan meliputi karakteristik 
lapisan batuan yang dapat memberikan respon terhadap adanya gelombang gempa. Karakteristik lapisan batuan yang lunak, tebal dan memiliki amplifikasi yang tinggi dapat membuat lapisan permukaan bumi mendapat pengaruh guncangan yang lebih kuat dan merusak.

\subsection{M etode Mikrotremor dan HVSR}

Mikrotremor dapat didefinisikan sebagai derau perioda pendek yang berasal dari sumber buatan atau dapat di definisikan sebagai getaran harmonik alami tanah yang timbul akibat getaran mikro bawah permukaan atau peristiwa alam lainnya. Metode mikrotremor telah banyak digunakan pada penelitian mengenai struktur tanah (soil investigation) untuk mendapatkan informasi mengenai karakteristik lapisan tanah (sedimen) yang digunakan dalam lingkup studi kegempaan.

Metode mikrotremor biasanya digunakan untuk menganalisis efek geologi permukaan

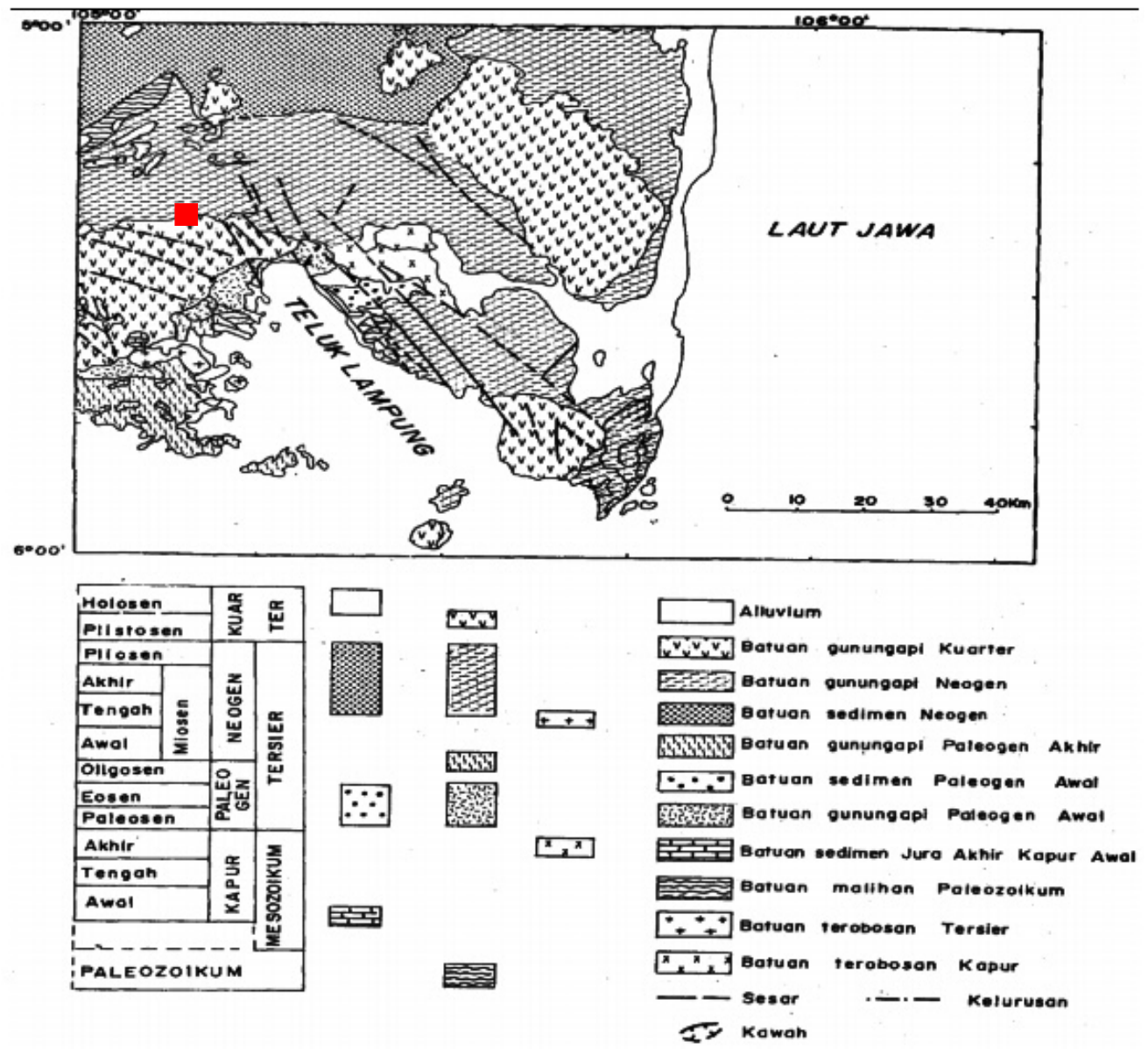

Gambar 1. Peta Geologi Regional Penelitian, kotak merah area penelitian (Mangga dkk., 1993).

dan karakteristik sedimen akibat gerakan tanah pada peristiwa gempa bumi (Lermo \& Chavez-Garcia, 1993; N akamura, 1989).

Data hasil pengukuran mikrotremor dapat dianalisis dengan menggunakan metode
H orizontal to Vertical Spectrum Ratio (HVSR). Metode HVSR adalah sebuah teknik empiris untuk memperkirakan karakteristik resonansi lapisan sedimen di bawah permukaan (Nakamura, 1989). Di tiap titik ukur akan 
dihitung besarnya nilai frekuensi resonansi dan amplifikasi (penguatan) lapisan sedimen.

A da dua parameter penting yang diperoleh dari pemrosesan data menggunakan metode HVSR yaitu frekuensi natural $\left(f_{0}\right)$ dan amplifikasi $\left(A_{0}\right)$. Kedua parameter tersebut menginterpretasikan kondisi geologi suatu daerah (Tanjung dkk., 2019).

\section{METODE PENELITIAN}

Penelitian ini dilakukan di area pembangunan RSP Unila, dengan melakukan pengukuran metode mikrotremor sebanyak 10 titik dengan 2 lintasan (Gambar 2). Gambar 2 menunjukan lokasi penelitian dengan warna hijau adalah vegetasi di area penelitian, warna coklat adalah bangunan RSP U nila.
Penelitian ini menggunakan metode microtremor single station dengan pengolahan data menggunakan software Geopsy dengan analisis HVSR. Prosedur penelitian dibagi menjadi beberapa tahapan, yaitu tahap akuisisi data, pengolahan data dan interpretasi data. Metode pengumpulan data menggunakan metode pengambilan data lapangan dengan menggunakan metode microtremor single station.

Pengukuran di lapangan menggunakan alat Reftek Seismometer dengan durasi pengukuran 20-30 menit. Durasi waktu ini digunakan untuk mendapatkan jangkauan nilai frekuensi yang maksimal sesuai dengan target. Data pengukuran terekam dalam bentuk sinyal dengan format .csv pada alat.

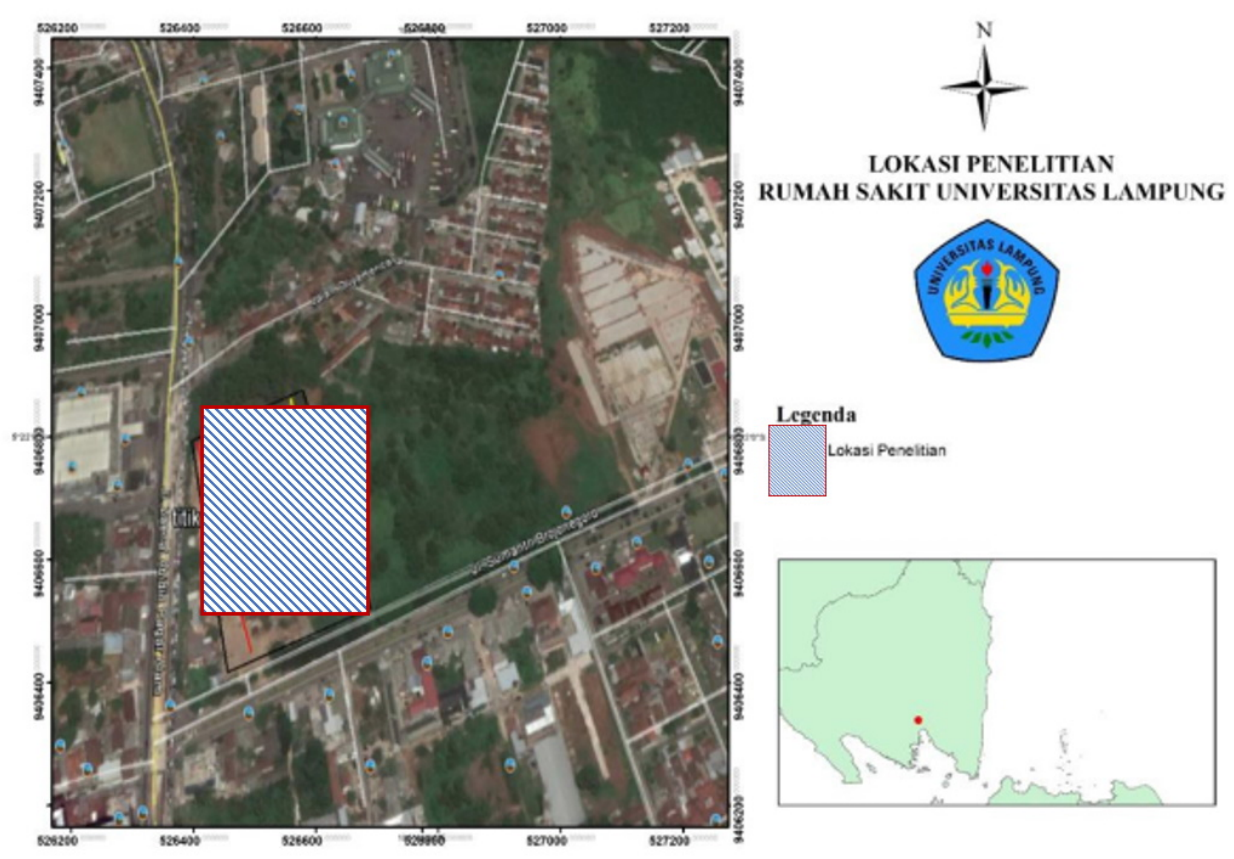

Gambar 2. Peta lokasi daerah penelitian.

Data mentah yang telah diperoleh dari pengukuran di lapangan dalam format .CSV kemudian di konversi ke format saf, setelah di konversi dilanjutkan pengolahan menggunakan Software Geophysical Signal Database for N oise A rray Processing (GEOPSY) versi 2.9.0.
Pengolahan data selanjutnya menggunakan metode H orizontal to Vertical Spectrum Ratio (HVSR) dengan mengacu pada SESAME (2004) untuk medapatkan nilai faktor frekuensi dominan $\left(f_{0}\right)$, faktor periode dominan $\left(T_{0}\right)$ dan faktor amplifikasi $\left(A_{0}\right)$. Komponen vertikal pada kurva HVSR 
menunjukkan besarnya nilai amplifikasi $\left(A_{0}\right)$ sedangkan komponen horizontal menunjukkan besarnya nilai frekuensi dominan $\left(\mathrm{f}_{0}\right)$. $\mathrm{H}$ asil pengolahan data mikrotremor dengan metode HVSR berupa periode dominan $\left(T_{0}\right)$, frekuensi dominan $\left(f_{0}\right)$ dan amplifikasi $\left(A_{0}\right)$ kemudian diolah dengan menggunakan software Surfer untuk mendapatkan sebaran titik penelitian.

Interpretasi dilakukan dengan melakukan analisis data hasil dari pengolahan data dengan metode HVSR yaitu analisis data periode dominan $\left(T_{0}\right)$, frekuensi dominan $\left(f_{0}\right)$ dan amplifikasi $\left(A_{0}\right)$. Dalam melakukan interpretasi juga digunakan data-data literatur dan juga data geologi sehingga diperoleh hasil interpretasi yang lebih valid.

\section{HASIL DAN PEMBAHASAN}

Analisis data mikrotremor dengan metode HVSR mengacu pada SESAME (2004) untuk mendapatkan data yang realibel. Hasil pengolahan data pada penelitian ini menghasilkan 2 jenis kurva yaitu clear peak dan multiple peaks. Jenis kurva clear peak lebih mendominasi dibandingkan jenis kurva multiple peak dimana dari 10 titik pengukuran hanya satu titik saja merupakan jenis kurva multiple peaks. Kurva clear peak adalah kurva yang ideal dalam pengolahan data mikrotremor karena realibity data kurva clear peak ini memiliki verifikasi yang terpenuhi berdasarkan SESAME European Project. Maka natural frekuensi yang didapat dari analisis puncak kurva ini dapat dipercayai sebagai natural frekuensi sitetersebut.

\subsection{Peta Persebaran Analisis Nilai Frekuensi Dominan $\left(f_{0}\right)$}

Bedasarkan pengolahan data dengan metode HVSR diperoleh peta sebaran nilai frekuensi dominan seperti pada Gambar 3 yang diinterpretasikan bahwa di area RS Unila memiliki nilai frekuensi dominan berkisar antara 0.65-1.2 Hz (Gambar 4). Nilai frekuensi dominan suatu daerah menunjukkan tingkat ketebalan sedimen dan jenis batuannya seperti dijelaskan pada Tabel $\mathbf{1}$.

Persebaran nilai frekuensi dominan di daerah penelitian $\left(0.65<\mathrm{f}_{0}<1 \mathrm{~Hz}\right)$ menurut Kanai (1983) (BMKG, 1998) merupakan daerah dengan klasifikasi jenis IV dengan indikasi ketebalan sedimen permukaannya masuk dalam kategori lebih dari 30 meter dan termasuk ke dalam batuan alluvial.

Lapisan batuan sedimen yang tebal memiliki bersikap rentan terhadap guncangan gempabumi. Semakin tebal lapisan sedimen suatu permukaan makaakan semakin rentan terhadap guncangan gempabumi.

\subsection{Peta Persebaran Analisis Nilai Periode Dominan $\left(T_{0}\right)$}

Bedasarkan peta sebaran nilai periode dominan pada Gambar $\mathbf{5}$ dapat diinterpretasikan bahwa di area RS U nila mempunyai nilai periode dominan diantara $0.6-1.5$ sekon.

Pengelompokan jenis tanah mengacu pada nilai periode dominan menurut OmoteNakajima (Kanai, 1983) dibagi menjadi 4 jenis yaitu jenis $A$ dengan nilai frekuensi antara 0.05-0.10 s (detik) yang mengindikasikan karakter jenis batuan sedimennya keras, jenis A dengan nilai periode $0.10-0.25 \mathrm{~s}$ (detik) mengindikasikan karakter batuan sedimennya sedang, jenis $B$ dengan nilai periode $0.25-0.4 \mathrm{~s}$ (detik) mengindikasikan karakter jenis batuan sedimennya lunak, dan jenis $C$ dengan nilai periode lebih dari $0.4 \mathrm{~s}$ (detik) mengindikasikan karakter jenis batuan sedimennya sangat lunak.

Persebaran nilai periode dominan pada area RS Unila sebesar $T_{0}>0.4 \mathrm{~s}$. Daerah tersebut merupakan daerah dengan klasifikasi jenis $C$ menurut Omote-Nakajima (Kanai, 1983) dengan indikasi karakter jenis batuan sedimennya sangat lunak berupa batuan alluvial, yang terbentuk dari sedimentasi delta, top soil, lumpur. Berdasarkan data dari peta geologi daerah penelitian merupakan endapan 
alluvium (alluvial) yang terdiri dari pasir, lempung dan kerikil. Daerah dengan lapisan sedimen lunak pada permukaan bumi bersikap rentan terhadap guncangan gempabumi.

\subsection{Peta Persebaran Analisis Nilai Amplifikasi $\left(A_{0}\right)$}

Berdasarkan peta sebaran nilai amplifikasi pada Gambar 6 dapat diinterpretasikan bahwa area Pembangunan Rumah Sakit Pendidikan Universitas Lampung memiliki nilai amplifikasi berkisar antara 3.33-5.62 kali.

Zona amplifikasi tanah menurut $M$ arjiyono (2010) dapat dibagi menjadi 4 keterangan
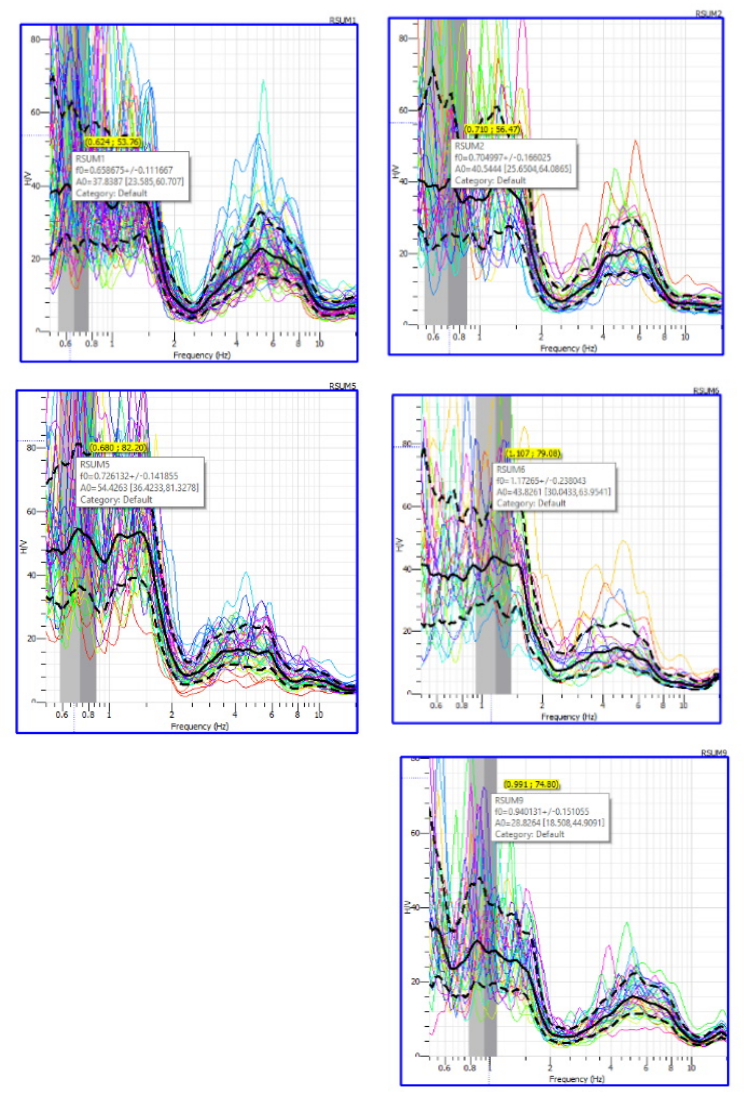
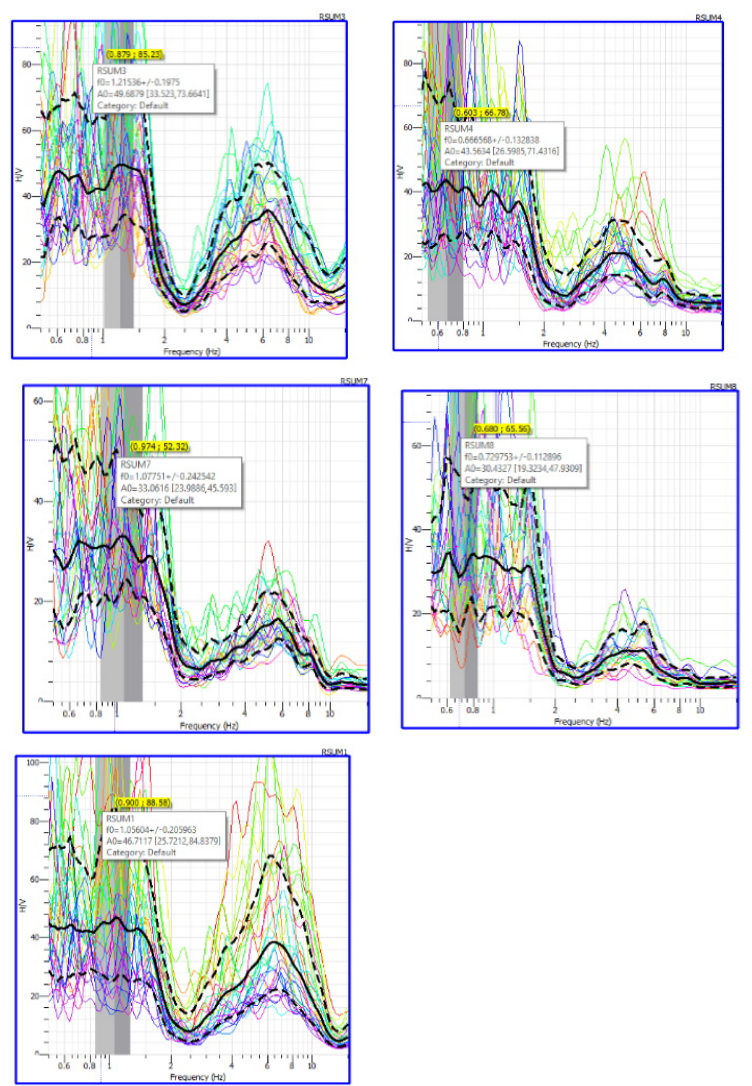

resiko yaitu kategori resiko rendah dengan nilai amplifikasi $\left(0<A_{0}<3\right.$ kali), kategori resiko sedang dengan nilai amplifikasi $\left(3<A_{0}<6\right.$ kali), kategori resiko tinggi dengan nilai amplifikasi $\left(6<A_{0}<9\right.$ kali $)$, dan kategori resiko sangat tinggi dengan nilai amplifikasi $\left(A_{0}>9\right.$ kali).

Berdasarkan hasil nilai perhitungan amplifikasi di Area Pembangunan Rumah Sakit Pendidikan Universitas Lampung berkisar antara 3.33-5.62 kali $\left(3<\mathrm{A}_{0}<6\right.$ kali), sehingga dapat dikatakan bahwa di Area Pembangunan Rumah Sakit Penididikan Universitas Lampung tersebut termasuk wilayah dengan kategori beresiko sedang terhadap guncangan gempabumi.

Gambar 3. Contoh kurva hasil pengolahan data microtremor dengan metode HVSR dengan 10 titik pengukuran. 


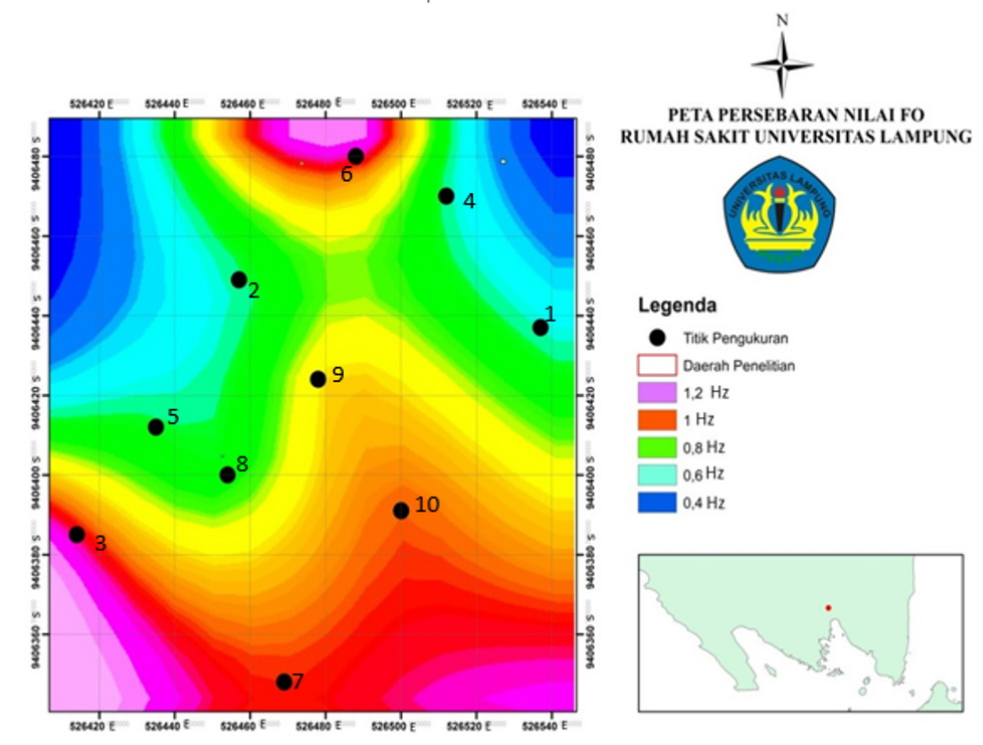

Gambar 4. Peta persebaran frekuensi dominan RSP U nila $\left(f_{0}\right)$.

Tabel 1. Klasifikasi tanah berdasarkan nilai frekuensi natural mikroseismik oleh Kanai (1983) (BM KG, 1998).

\begin{tabular}{|c|c|c|c|c|}
\hline \multicolumn{2}{|c|}{ Klasifikasi Tanah } & \multirow{2}{*}{$\begin{array}{c}\text { Frekuensi Natural } \\
6.67-20\end{array}$} & \multirow{2}{*}{$\begin{array}{c}\text { Klasifikasi Kanai } \\
\text { Batuan tersier atau } \\
\text { lebih tua. Terdiri dari } \\
\text { batuan H ard sandy, } \\
\text { gravel, dan lainnya. }\end{array}$} & \multirow{2}{*}{\begin{tabular}{l}
\multicolumn{1}{c}{\begin{tabular}{c}
\multicolumn{1}{c}{ Ketebalan } \\
sedimen
\end{tabular}} \\
Sangat tipis dan \\
didominasi batuan \\
keras.
\end{tabular}} \\
\hline TipeIV & Jenis I & & & \\
\hline TipellI & Jenis II & $4.0-10$ & $\begin{array}{l}\text { Batuan tersier atau } \\
\text { lebih tua. Terdiri dari } \\
\text { batuan H ard sandy, } \\
\text { gravel, dan lainnya. }\end{array}$ & $\begin{array}{c}\text { Kategori } \\
\text { menengah } 5-10 \mathrm{~m} .\end{array}$ \\
\hline Tipell & Jenis III & $2.5-4$ & $\begin{array}{l}\text { Batuan alluvial } \\
\text { dengan ketebalan } \\
\text { lebih dari } 5 \mathrm{~m} . \\
\text { Terdiri dari sandy } \\
\text { gravel, sandy hard } \\
\text { clay, loam, dan } \\
\text { lainnya. }\end{array}$ & $\begin{array}{c}\text { Kategori tebal } \\
10-30 \mathrm{~m} .\end{array}$ \\
\hline Tipel & JenisIV & Kurang dari 2.5 & $\begin{array}{l}\text { Batuan alluvial yang } \\
\text { terbentuk dari } \\
\text { sedimentasi delta, top } \\
\text { soil, lumpur, dan } \\
\text { lainnya. Kedalaman } \geq \\
\quad 30 \mathrm{~m} \text {. }\end{array}$ & Sangat tebal. \\
\hline
\end{tabular}




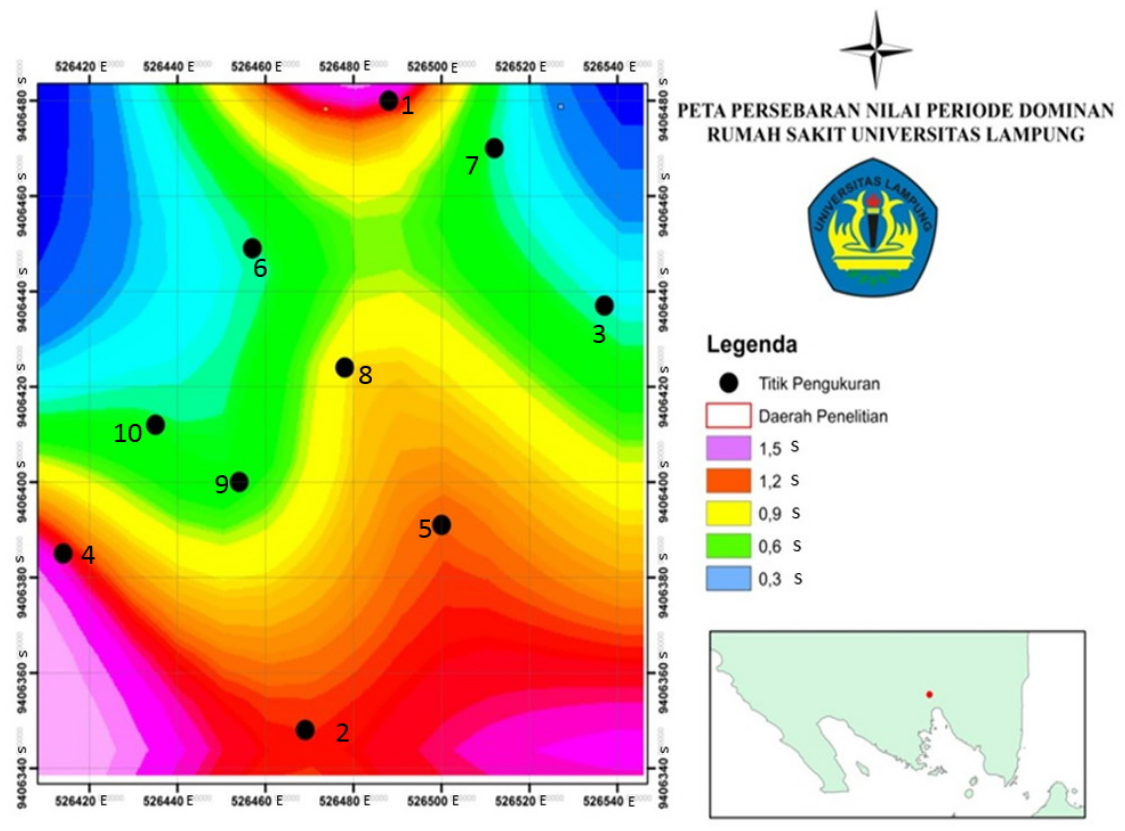

Gambar 5. Peta persebaran periode dominan $\left(\mathrm{T}_{0}\right)$.

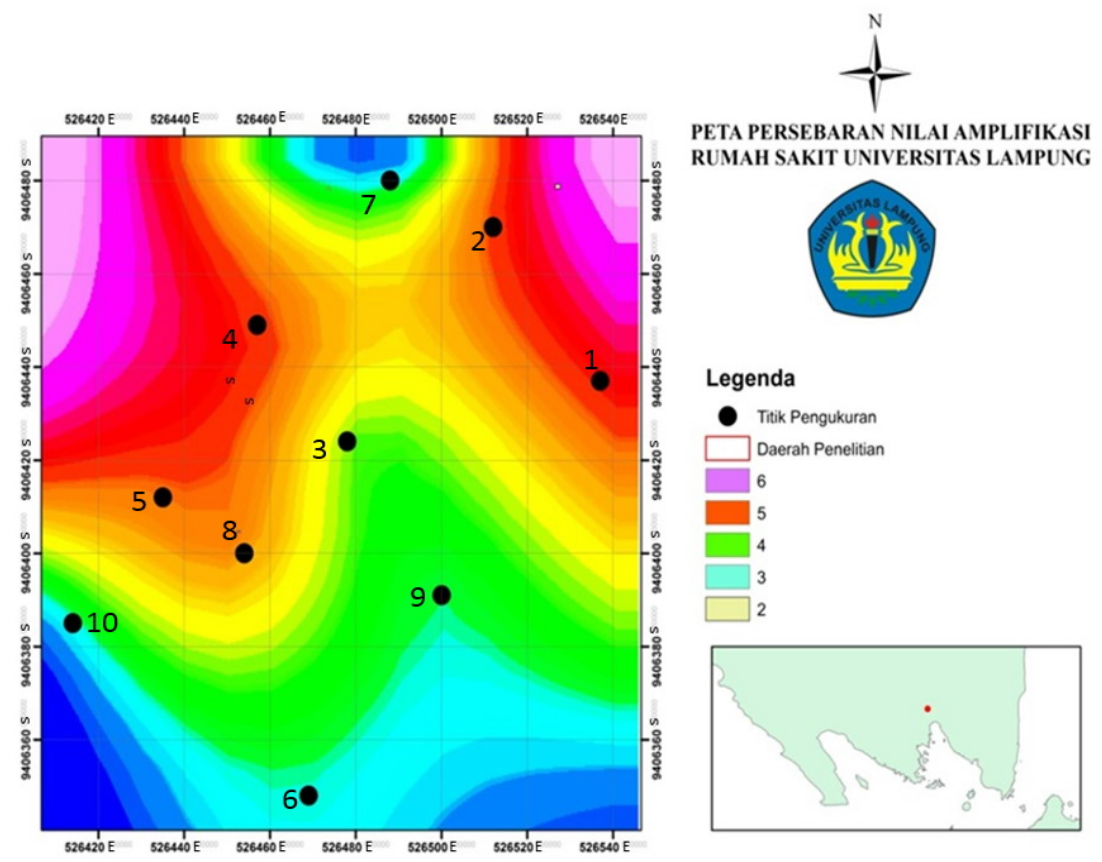

Gambar 6. Peta persebaran amplifikasi.

\section{KESIMPULAN}

Kesimpulan yang didapatkan pada penelitian ini diantaranya:

a. Daerah penelitian memiliki nilai frekuensi dominan berkisar antara 0.65-1.2 Hz yang mengindikasikan ketebalan sedimen permukaannya lebih dari 30 meter.

b. Daerah penelitian mempunyai nilai periode dominan di antara 0.6-1.5 sekon dan dengan indikasi karakter jenis batuan 
sedimennya sangat lunak berupa batuan alluvial, yang terbentuk dari sedimentasi delta, topsoil, lumpur.

c. Daerah penelitian memiliki nilai amplifikasi 3.33-5.62 kali dan merupakan daerah dengan kategori resiko sedang.

d. Daerah penelitian termasuk daerah yang rentan ketika terjadi gempabumi ditandai dengan lapisan sedimen yang tebal dan lunak serta nilai amplifikasi menengah.

\section{UCAPAN TERIMA KASIH}

Terima kasih kami ucapkan kepada Fakultas Teknik Universitas Lampung sebagai pemberi dana pada kegiatan penelitian pada skema DIPA FT Unila.

\section{DAFTAR PUSTAKA}

BMKG. (1998). Sumber Daya Geologi. Buletin M eteorologi Dan Geofisika N o.4.

BMKG. (2021). Gempabumi Wilayah Lampung. Buletin Geofisika. Buletin Geofisika BM KG.

Daryono. (2011). Indeks Kerentanan Seismik Berdasarkan Mikrotremor pada Setiap Satuan Bentuk lahan di Zona Graben Bantul, Daerah Istimewa Yogyakarta. U niversitas Gadjah M ada.

Hesti, Pramumijoyo, S., \& Wintolo, D. (2018). Interpretasi Karakteristik Dinamika Sedimen Berdasarkan Analisis Mikrotremor di Daerah Prambanan Kabupaten Sleman Propinsi DIY dan Klaten Propinsi Jawa Tengah, Indonesia. Jurnal Geofisika, 16(01), 09-14.

Jamroni, A., Imran, A. M., \& Azikin, B. (2017). A nalysis of M icrotremor Data U sing H orizontal to Vertical Spectral Ratio (HVSR) Method of $M$ akassar, South Sulawesi. International Journal of Engineering and ScienceA pplications, 4.

Kanai, K. (1983). Seismology in Engineering (Tokyo Univ).
Lermo, J., \& Chavez-Garcia, F. J. (1993). Site Effect Evaluation Using Spectral Ratios with Only One Station. Bull. Seismol. Soc. Am. 83, 1574-1594.

$M$ angga, S. A., A mirudin, Suwarti, T., Gafoer, S., \& Sidarto. (1993). Peta Geologi Lembar Tanjung Karang, Sumatera.

M arjiyono. (2010). Estimasi Karakteristik Dinamika Tanah Dari Data Mikrotremor Wilayah Bandung. Institut Teknologi Bandung.

M arsyelina, M., Wibowo, N. B., \& Darmawan, D. (2014). Karakteristik Mikrotremor dan Analisis Seismisitas pada Jalur Sesar Opak, Kabupaten Bantul, Y ogyakarta. Jurnal Sains Dasar, 3(1), 95 - 101.

Mucciarelli, M., Herak, M., \& Cassidy, J. (2007). Increasing Seismic Safety by Combining Engineering Technologies and Seismological Data. Springer.

Mulyaningsih, S. (2010). Pengantar Geologi Lingkungan. Jalasutra.

Nakamura, Y. (1989). A Method for Dynamic Characteristics Estimation of Subsurface using Microtremor on the Ground Surface.

Satria, A., Larasati, N., Lestari, W., \& Dewi, I. K. (2019). Analisis Mikrotremor Berdasarkan M etode HVSR (Horizontal to Vertical Spectral Ratio) Untuk Mengetahui Indeks Kerentanan Seismic Kota Jambi. Jurnal Teknik Kebumian, $1(1)$.

SESAME. (2004). Guidelines for The Implementation of The H/V Spectral Ratio Technique on Ambient Vibrations Measurements, Processing and Interpretation. European Commission - Research General Directorate Project.

Tanjung, N. A. F., Yuniarto, P. M., \& Widyawarman, D. (2019). Analisis Amplifikasi dan Indeks Kerentanan Seismik di Kawasan FMIPA UGM Menggunakan Metode HVSR. Jurnal Geosaintek, 5(2), 60-67. 